\title{
DEATHS IN DISTANCE
}

\author{
Jan Kevin Rivera \\ jankevinrivera@gmail.com
}

\begin{abstract}
About the Author
Jan Kevin Rivera manages government and policy affairs for a social enterprise. He graduated with a BA in Broadcast Communication, cum laude from the University of the Philippines Diliman. He attended high school at the University of Santo Tomas where he won an Ustetika, the university literary prize. He was a Fellow for Creative Nonfiction at the National Writers Workshops of Silliman University and UST.
\end{abstract}


My roommate found me sprawled on the couch one midnight in July, tinkering with my phone, killing time until sounds deadened to a faint buzz. There was always a faraway noise - speeding motorcycle, honking bus - that hummed around our unit, in a building cornered by a highway and a train track.

"My grandmother just died," she announced in the middle of our dim kitchen.

I looked up to examine her: petite, dressed in neutral business tones, the day's stress weighing on her. She was how she came home every day - overworked and overwhelmed. I observed her face for signs of sadness, of shock, but it was just tired as she stared back at me.

"Are you okay?" I asked in an even tone. It would have been an "I'm so sorry to hear that" had there been traces of distress in her voice. We were high school friends before roommates. We got along well enough to share stories and a living space.

"I don't remember her," she said, sitting beside me. "So I don't know what to feel."

In the tug of war of broken families, she gravitated towards the side that had won. She wasn't privy to the decision behind the set up - a court order, a secret negotiation. From what I knew, she barely connected with her father, let alone relatives from that side. She hadn't bothered to know them, and they hadn't known her.

A feeling between indifference and sadness, I said to her.

"How do you know this?" she asked, her tone suggesting that I was spot on. I continued to scroll down my Facebook feed: here was an aunt that I avoided in the common spaces that we circled in, a distant relative showing off her kid in another country, cousins who kept appearing as "People You May Know."

On our side of clannish Catholic Manila, the stories were all the same. The stereotype of close family ties untangled itself, until we were old enough to move as far as the links could stretch, never to sever them completely. When someone's unfortunate end came, we traced back the line to mourn in emotional confusion. We had no way to distinguish sadness, pain, guilt, anger, regret, remoteness from one another. They came unexpressed and muddled in life - even more so in death. 
Feliciano, my paternal grandfather, was a policeman back when Manila's Finest were doing a dignified job. He always had a look - scrunched eyebrows, open-mouthed frown, and a piercing stare. My parents didn't need to intone the Boogeyman or the racial profile of a kidnapper for my wrongdoings. The imagined booming voice of my grandfather, peppered with Tagalog invectives, was enough to keep me in line.

That was how Lolo Fel seared his image in my head - tough, no-nonsense, with little affection to give. That image has always been coupled with the pain of his hilot.

The way he healed us was almost supernatural. As a sickly kid, my parents would bring me to him. He would look me in the eye. If they were not the same size, something was amiss. He would find it. One press of his thumb on an elbow joint and I would yelp. The pain was caused by joint inflammation, but nothing Vicks Vapor Rub and his forceful kneading wouldn't solve.

That went on for years until I was older, growing surer over the years that I would never identify with my grandfather's love for basketball and women. He would look at me with piercing eyes, checking to see if my own were misaligned. I would cringe under the scrutiny, recalling all the things that I had done with boys behind closed doors.

During hilot, Lolo Fel's questions got more pointed but never direct, delivered with the brusqueness of a police interrogation. My changing reactions towards them became our substitute to confrontations. I cried as a kid, winced and pulled back as a pre-adolescent, and braved a poker face as a teenager.

Whenever Ideveloped a fever in college, my mom was quick to suggest visiting Lolo Fel. I didn't tell her that I had grown reliant on ibuprofen; because with it came the silent, gradual acceptance that my sins were just after-school activities.

The news of my grandfather's death came on a rainy June afternoon, during my last year of college in 2011. I was sitting in a dark corner of the classroom, viewing a film in scriptwriting class. 
My dad's text was terse: Come home soon. Lolo Fel is gone.

I pocketed my phone and stared at the projected film, recalling the trail of conversations leading towards that moment. It was a mishmash of events: sudden painful headaches, dwindling memory, back-and-forth trips to the hospital, failing limbs, a home for the terminally ill in northern Manila. Whatever excuses I had told my parents then - school project, thesis, Student Council activity - were enough to justify my absence in Lolo Fel's last days.

After dismissal, I trudged on the muddy path towards my then-boyfriend's college building. He looked up from where he was sitting and saw my blank expression.

"Lolo died," I said in a quick rush. "I need to get home."

My boyfriend commuted with me, all the while asking if I was okay. At one point, he reached out for my hand and squeezed it. It was the calloused, unmistakable palm of a man.

I pulled back and looked up. I was expecting piercing eyes of an old man. Instead my boyfriend's surprised, questioning gaze stared back at me.

It seemed that my grandfather's generation was giving way. Three years later, well into my young professional career, Lolo Fel's older brother Redentor was diagnosed with advanced liver cancer.

Lolo Red was a white, plump man with traces of muscle packed into his frame, signs of what used to be an active life. Like Lolo Fel, he always looked serious. He was taken to short pleasantries, but unlike Lolo Fel, Lolo Red's stoicism made more sense. He raised five children after losing his wife to brain cancer in the early nineties.

Lolo Red had a quiet hardness in him. He had a tone of voice that always bordered on nonchalance. In the hushed conversations that I wasn't meant to hear, my relatives assumed that he was never the same. Grief came in slow waves through the years, eroding what was left of Lolo Red. His wife's passing defined his demeanor and created a distance that emanated in family reunions. 
But for me, Lolo Red's aloofness had always been a good refuge. He was less abrasive than Lolo Fel or any of my other relatives. There was no need to ask why I didn't bring a girlfriend, or why my brother didn't either. Small talk was all he could share, but with me, perhaps more. I saw a flicker of affinity in his eyes when he found out that I was editing the high school paper. When I told him that I had been accepted into the national university, he appraised me from across the table - a strange mixture of admiration and sadness.

"Just like Jer," he said, but more to him than me.

I volunteered to visit Lolo Red in the hospital in his last days, before the cancer claimed him completely. He was sick and gangly, as I had imagined Lolo Fel would be like on his deathbed. He recognized me and smiled, but it was close to a grimace.

The air conditioner thickened the smell of damp beddings and medicine. My aunt and uncle had the unmistakable bearings of hopelessness: eyes that had not slept in days, clothes that seemed a day old, conversations that trailed off in midsentence. The inevitable was inching its way towards Lolo Red. We sat around him, filling the silences with attempts at conversations.

When it was time for us to go, I squeezed Lolo Red's hand, telling him a useless "Get well soon." Tita Mia, my cousin Andrea, and I shared a quiet car ride home.

"Will Tito Jer come home?" asked Andrea, the innocence in her voice palpable. She was referring to Jeremy, Lolo Red's US-based son who hadn't visited Manila in twenty years.

There was a long pause before any of us answered, unsure of what to say.

"I don't think he will," my aunt replied, her tone suggesting finality in the conversation.

My cousin kept quiet for the rest of the car ride. She didn't know it yet, but she was learning our ways well. We passed on the weight of our evaded explanations to each member of the family, from one generation to another.

The little that I knew of Tito Jer was patched together from Sunday lunch conversations through the years. 
Jeremy was the third son among five, singled out among cousins who coasted along in academics. He always had a book in hand, never to be cajoled into their games. He was serious and stuck up, their tones seemed to suggest. He was a consistent honor student from grade school to college, culminating in an invitation to join the largest technology firm in the US. With his computer science degree, he flew to the East Coast for the job. He left when the country was gripped by coup attempts and rotational blackouts, while his family was reeling from his mom's death.

"Jer was an achiever." It was always declared in pride and jest.

"He's like you." This addendum became unavoidable when I began to bring home more medals than my brother, when I showed signs of a certain conceit, when I chose to attend the same university against my parents' wishes.

For the longest time, my mental image of Tito Jer was the packs of imported chocolates sent to cousins and their families. During his Yuletide absence, I was free to make up the unsaid. A pack of Twix was, "Mom died. I have no reason to stay there." A set of Toblerone was “Sorry, I couldn't make it this year. I won't be missed."

One sealed bag of Snickers - no label, just up for grabs - was "I don't know who you are."

I found myself in a cab one sunny Saturday morning in August. My destination was a memorial house in Marikina - the last day for Lolo Red's wake before the Sunday funeral.

The viewing rooms were always the same in my family: air conditioner in full blast, a long sofa, draped curtains in somber colors, rows of mono-bloc chairs, and a blanket strewn somewhere, evidence of someone pulling an all-nighter.

The room was empty when I got there. It was still noon. Relatives were expected to pour in later that day for Lolo Red's final viewing. 
Someone called me by my childhood name from behind. It was Tito Peter, Lolo Red's fourth son. Like all men in our family, Tito Peter shared the same scrunched, untamed eyebrows and intense, unblinking stare, like secret pain showing on our facial expressions.

"Your mom and dad aren't with you?" he asked, looking around the room.

"I didn't come from home," was my clipped answer. Ever since moving out, I had only been with my parents on weekends. Those weekend visits were reduced to a phone call of harried apologies when work took over my Saturdays.

A man walked in behind Peter. He looked like Lolo Red - a younger version of the plump, white figure with grayish hair and glasses.

“This is Jeremy, my brother," Tito Peter said, introducing me to a relative as if he were a stranger. "Son of our cousin," Tito Peter explained to Tito Jer. "You remember his mom? Yeah, they ended up together. He was born after you left. "

Tito Jer offered a hand. I shook it uneasily, forgetting the tight grip that I had learned to do in my job.

"You look like your dad," Tito Jer said. "And Tito Fel."

I shrugged, growing more awkward in his presence. The American accent tingled in my ear, like a new song in my decided list of familiar tunes. He excused himself and went to the back room, preparing utensils for the guests.

I sat by myself in a corner, alternating between looking at my phone and observing Tito Jer from the corner of my eye. He reigned in the accent and answered with polite replies. Like Lolo Red, he talked to relatives in a quiet, guarded manner.

Just then, my older brother sat beside me. I noticed that my parents settled themselves among relatives.

"How are you?" I asked him. I barely knew what had been happening with him. All I knew was that he took a new job without consulting anyone in the family. He worked at the head office of a clothing retail giant, something he had decided on after failing the engineering boards twice. One dinner, he just announced that he was not re-taking the boards anymore, and that he had accepted a job offer. 
"I'm okay," Kuya replied, shrugging with disinterest. Experience taught me not to prod further.

"Have you met Tito Jer?" I asked, opening another topic. Experience also taught me that my brother was not one to ask back how I was doing.

"Yes," Kuya said with a chuckle, but nothing else.

"I heard him talk to Tita Bridget about the order of speakers in the eulogy," I added for lack of anything to say. "He said, 'I'm not the favorite, so you decide."

He stayed silent for a while - maybe in remembrance of the years we spent figuring out who outranked who in the family. In time, we became less interested in equal treatment as we got caught up in our own entanglements. My parents, it seemed, had been caught up in theirs, too.

“That's funny," he said, though his tone suggested otherwise.

We spent the rest of the afternoon steering clear of any other touchy topics. He showed me the new game he installed on his phone. He told me how the pet dogs destroyed mom's new plants. He raved about a new restaurant that he ate at with a male friend-a name that I heard him mention before but was never discussed further.

The room was packed with relatives at dusk. We settled on our mono-bloc chairs as we listened to the eulogies.

My second cousin Lawrence spoke first. He was Lolo Red's first grandson, two years my senior. Once, he saw me walking around the business district with another boy. We gave each other a nod of acknowledgement and went our separate ways.

Tita Mia came next. She reminisced about Lolo Red acting as her second dad. Lolo Fel, I assumed, was not the best provider. She stepped down from the podium.

Tito Jer took her place. 
"I'm Jeremy, Red's son from the States," he said to the crowd. The one who was away, he seemed to imply.

Tito Jer shared stories with us. He recalled how Lolo Red dictated the steps to solve a Math problem while driving, while coping with his wife's cancer. He remembered how Lolo Red provided for them, working hard as a director when the television industry was in its heyday. He apologized to Lolo Red, for sins and shortcomings that weren't elaborated.

"My dad was also forgiving," Tito Jer said in tears, looking down as he gathered himself. He told us about his father's patience as he raised five children, often tolerant of their misbehaviors as kids.

"If dad were here right now, I know he'd forgive me," Tito Jer concluded to a tearful crowd. Forgiven for what, I was not sure. Even in mourning, we spoke between the lines.

Tita Bridget gave the final speech. Acceptance, Lolo Red had told her. His death was just a matter of acceptance.

The crowd started to disperse for supper after the speeches. I wolfed down mine as I looked for my mom in the crowd. I looked at her, eyes bloodshot from crying. Mom has always been a softie. I told her that a pile of work waited on my desk in Makati.

"Let's have dinner this week," I said in the din of voices in the room. She nodded and touched my arm. It would play out the same way it always did. We would talk about anything - the dogs, the plants, the neighbors - but never about her new separate room, Dad's prolonged overtime hours, or Kuya's male friend who often slept over.

The thick crowd walked around me as I looked for Kuya. He was eating supper on a paper plate, in a corner by himself. He looked up and noticed me. I held out a thumbs-up sign and mouthed "Next weekend." He nodded at me and waved me off. Walking away from the viewing room, I made a mental note to buy brownies for Kuya and his friend.

I ran into Tito Jer outside. I took advantage of a pause in his flurry of handshakes and condolences from guests. 
"Tito Jer," I began as a tentative greeting. I held out my hand when he looked at me. "I'll go ahead. It was nice meeting you."

He returned my handshake with a soft, silent appraisal. I knew then that it would be the first and last time that I'd see him.

I walked on and found my dad smoking in the parking lot. He looked at me, then at the overstuffed bag that I was lugging. My repurposed gym bag was bursting with office clothes good for weeks.

"You're not going home with us?" he asked, though he already knew the answer.

"No," I said with an apologetic smile. "I have work."

Dad exhaled the smoke to its last puff. If we were younger, this would become a fight. "School project?" he used to mock my excuses in high school, challenging me to reveal what - who - had really kept me late.

But these days, we just let each other be.

"Take care," he said. "Give my regards to Miguel." He referred to the man who drove me home with my dirty laundry on weekends, after we've had a late dinner somewhere far away from our families.

I nodded and made my way to Tita Mia's car, asking her if I could hitch a ride.

I kept quiet throughout the ride, lost in thought. My mind reeled back to Tito Jer's speech.

Maybe Tito Jer didn't need to be in the US. Maybe another city was enough, here in the national capital where traffic made places seem farther than they were.

Maybe he clung on to the last scraps of his relationships - to salvage whatever affection he had for his siblings, to mend whatever what was not fought about with Lolo Red, to dissipate the last traces of anger at anyone who didn't understand.

Maybe he left because he and his siblings were becoming adults, and his dad had been one all along. They were not family members who were required to get along. They were grown-ups who didn't have the answers to each other's problems, and that was okay. 
Maybe in distance, Tito Jer learned to forgive. Maybe he was sure that he was forgiven.

That was the thing about the unsaid: You were free to fill in the gaps.

My roommate found me working on my bed, the screen of the laptop illuminating the room. It was almost Sunday dawn as I rushed to finish a job application, something that I hadn't told my parents as well.

"How was the wake?" she asked as she got ready for bed.

I gave her a non-committal grunt and continued working. She shrugged and settled on the top bunk.

"Did you cry?" I asked out of nowhere. "Did you cry during your grandmother's funeral?"

"Yes," she said while stifling a yawn. "They were saying nice things about her."

The living rooms she and I had left behind were saddled with sidestepped strains. Estranged family members were never estranged. They simply stayed far enough to forget and be forgotten. There were no gay grandsons, just grandsons without girlfriends.

But in everything that was unspoken, we found it in ourselves to curate certainties - "nice things" - from passing lives.

During our last Christmas together, Lolo Red was still urging me to give law school a try, saying that I had the brains for it.

Lolo Fel bought me a policeman toy set as a kid. It was my favorite. I remember running around, making pew-pew sounds with my gun and playfully handcuffing my brother. 
In those days, Dad would come home to the ancestral house that was big enough for three families. The looming largeness of the house made us stay in one room, curled beside each other in the masters.

Those moments were clear memories in the tattered expanse of our relationships, before boyfriends and baggage, when fathers and sons forgave easily. Everyone was home, staying in rooms absent of tensions. Those memories were the few things that we were sure of, highlighted by the reality of impermanence.

Soft Sunday sunlight seeped through the curtains. The distinct rumble of trucks on the superhighway faded in and out. This city never rested, these sounds were never still. That dawn of Lolo Red's funeral, the faint buzz in our unit bounced off the spaces I have yet to fill, around feelings I haven't defined.

Tuning out the noise of my terrain and thoughts, I finally closed my eyes to sleep.

Names have been changed. 